\title{
CHARACTERIZATION OF NEW RECYCLED POLYMER SHOTS ADDITION FOR THE MECHANICAL STRENGTH OF CONCRETE
}

\author{
VPLIV DODATKA RECIKLIRANIH POLIMERNIH ŠIBER NA \\ MEHANSKO TRDNOST BETONA
}

\author{
Mateusz Jackowski, Marcin Malek*, Wojciech Życiński, Waldemar Lasica, \\ Mariusz Owczarek \\ Military University of Technology in Warsaw, Faculty of Civil Engineering and Geodesy, Poland \\ Prejem rokopisa - received: 2019-07-16; sprejem za objavo - accepted for publication: 2020-01-29
}

doi:10.17222/mit.2019.160

\begin{abstract}
This work summarized the experimental results of modified concrete samples by recycled polymer shots. The polymer shots were equal to $(5,10,15) w / \%$ of the amount of cement. The main purpose of this research was to characterize the final mechanical strength of the concrete samples and investigate the basic physio-chemical properties of the newly fabricated concrete. The concrete mixtures were prepared using a new, laboratory-calculated recipe with polymer shots, basalt as an aggregate, deflocculant based on polycarboxylates and portland cement $(42.5 \mathrm{MPa})$. After $28 \mathrm{~d}$ the mechanical properties such as the compressive strength and bending strength were characterized. The initial and final binding times were determined. SEM micrographs and LM images were taken. The thermal conductivity was also measured. Additionally, the thingness test was investigated. The presented research shows that the tested samples containing polymer shots exhibit lower mechanical properties than the samples without modifications. Compared to the reference sample the rest of the investigated properties are higher. These kinds of concrete are very promising for applications in civil engineering in special building constructions in the future. Keywords: concrete modifications, polymer shots, mechanical properties, special building constructions
\end{abstract}

$\mathrm{V}$ tem prispevku avtorji povzemajo opis eksperimentalnih rezultatov modifikacije betona $\mathrm{z}$ dodatkom recikliranih polimernih šiber (krogel). Dodatek polimera je bil enak vsebnosti 5-, 10- in 15-tih masnih \% cementa. Glavni razlog te raziskave je bil določitev mehanske trdnosti vzorcev in fizikalno-kemijskih lastnosti izdelanega betona. Betonske mešanice so bile pripravljene z uporabo novih laboratorijskih receptov z dodatkom polimernih krogel, bazaltnega agregata, deflokulanta na osnovi polikarboksilatov in Portland cementa (42,5 MPa). Po 28 dneh so določili mehanske lastnosti betonov, kot sta tlačna in upogibna trdnost. Avtorji so določili začetek in konec vezanja betonov, izvedli preiskave na optičnem (LM) in vrstičnem elektronskem mikroskopu (SEM) ter določili njihovo toplotno prevodnost. Dodatno so izvedli tudi teste njihove realne kvalitete. Rezultati raziskave so pokazali, da imajo vzorci, ki vsebujejo dodatek polimernih šiber slabše mehanske lastnosti kot jih ima nemodificiran beton, medtem ko so ostale lastnosti višje (boljše). Avtorji v zaključku ugotavljajo, da bo v prihodnosti ta vrsta modificiranega betona zelo uporabna $\mathrm{v}$ gradbeništvu za izdelavo specialnih konstrukcij.

Ključne besede: modifikacija betona, polimerne šibre (krogle, naboji), mehanske lastnosti, specialne zgradbe

\section{INTRODUCTION}

Concrete was already produced in antiquity and it led to the currently used building materials. For this purpose, the process of crushing and burning gypsum or limestone was used primarily. When sand and water were added to these materials, they became a mortar, which was a plaster-like material. It was used to stick stones to each other. For thousands of years, these materials have been improved, and finally, by combining with others, transformed into modern concrete. ${ }^{1-3}$

Currently, concrete is the most commonly used building material. Due to the numerous requirements posed by subsequent realizations of buildings, it is possible to obtain the necessary properties of hardened concrete by modifying the concrete mix (higher compressive strength, lower porosity, etc.) with different additions, e.g., zeolite, kaolin, and polymer shots. ${ }^{4-7}$

*Corresponding author's e-mail:

marcin.malek@wat.edu.pl (Marcin Małek)
The polymer shots are made of urea-type components. Urea, also known as carbamide, is an organic compound with the chemical formula $\mathrm{CO}\left(\mathrm{NH}_{2}\right)_{2}$. This amide has two $-\mathrm{NH}_{2}$ groups joined by a carbonyl $(\mathrm{C}=\mathrm{O})$ functional group. Polymer shots are mostly used as an abrasive that allows faster processing of the details, where damage and deformation of the surface are undesirable. It is a high-quality, ecological, clean, reusable abrasive..$^{8-10}$

Many authors have shown effect of polymer additions on concrete. ${ }^{1-15}$ This study contains the results of our own experimental research on concrete modification conducted with recycled polymer shots.

\section{MATERIALS AND METHODS}

The subject of these studies was polymer shots used as an addition to concrete mixtures. Analysis of the microstructure of the additives used during the execution of the concrete was performed with a TransmissionReflection Microscope. Concrete mixtures with polymer 
shots added for consistency, $\mathrm{pH}$ and porosity were tested. The basic thermal parameters of the concrete samples using the ISOMET 2114 gauge were tested. The variability of the thermal parameters of the concrete samples, subjected to drying in the open air and dryer at a temperature of $40{ }^{\circ} \mathrm{C}$ during $18 \mathrm{~h}$ was evaluated.

Portland cement, basalt aggregates of $0-0.063$; $0.063-0.125 ; 0.125-0.250 ; 0.250-0.500 ; 0.500-1.000$; $1.000-2.000$ and $2.000-4.000 \mathrm{~mm}$, water, deflocculant based on polycarboxylates and polymer shots were used to fabricate the concrete mixtures. Drinking water, also known as potable water, has been used as the mixing water for concrete (according to PN-EN 1008:2004). Also, to three recipes polymer shots (shortcut PS) instead of the same amount of cement were added $(5,10$ and 15$) w / \%$. The recipe without polymer shots addition, as a reference sample, was treated. Test results of the samples containing the additive in all figures and tables were marked as PS5, PS10 and PS15. In addition, the sieve analysis for the filler was made. Samples fabricated under laboratory conditions (52\% humidity and $22{ }^{\circ} \mathrm{C}$ temperature) and with mechanical mixer and aluminum reactor were carried. After adding the powder products and mixing them for $1 \mathrm{~min}$, liquid products were added. For 5 min the whole mixture in a mechanical mixer were mixed. The concrete mixture was transported into steel forms and compacted with the vibration method in $45 \mathrm{~s}$.

Testing of the compressive strength of concrete in accordance with PN-EN 12390-3: 2002 on cubic samples $(150 \times 150 \times 150) \mathrm{mm}$ was carried out. Dried and cleaned of any loose impurities the samples were placed between the pressure plates of the testing machine in such a way that the load was applied perpendicular to the direction of sample formation. All samples under laboratory conditions (52\% humidity and $22{ }^{\circ} \mathrm{C}$ temperature) and with a $0.5 \mathrm{kN} / \mathrm{min}$ displacement of load were tested. The average compressive strengths were calculated.

Testing of the concrete's tensile strength in bending was carried out in accordance with PN-EN 12390-5: 2002 on rectangular samples with dimensions of $(100 \times$ $100 \times 500) \mathrm{mm}$. Dried and cleaned of any loose impurities the samples were placed on two support rollers. The sample was destroyed by applying a force constantly rising to the sample through the upper roller. All the rollers are made of steel with a diameter of $20 \mathrm{~mm}$. Tested samples were placed in such a way that the pressure roll of the testing machine applied the load perpendicular to the direction of the sample's formation.

\section{RESULTS}

The sieve curve of basalt aggregates (filler) is shown in Figure 1. The results of the light-microscopy examination after mechanical tests are shown in Figure 2.

The distribution of individual grains in the concrete mix shows the correct mixing time of the concrete mix-

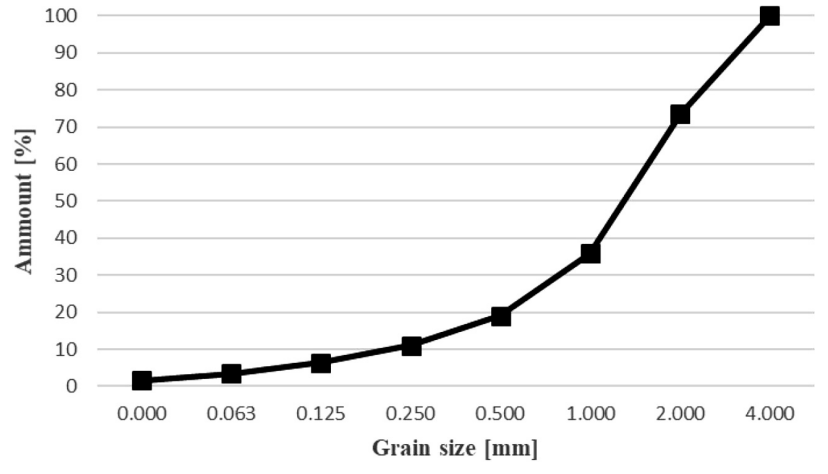

Figure 1: Sieving curve of basalt aggregate (filler)

ture. The amount and small quantity of air voids in the concrete mix shows the appropriate vibration time of the mixture.

The tested addition is shown in Figure 3. The image presents that polymer shots' typically sharp-edged structure and its particles are nonregular and exhibit different sizes.

During the slump test comparable results for each of four recipes were obtained. All results -presented in Table $\mathbf{1}$ - are within the range of dry consistency in accordance with EN 12350-2:2011. Table 2 shows the results of the $\mathrm{pH}$ tests for all four recipes.

Table 1: Results of the cone fall tests

\begin{tabular}{|c|c|c|}
\hline Recipe & cone fall $(\mathrm{cm})$ & Consistency \\
\hline Reference & 1.5 & dry \\
\hline PS5 & 1.1 & dry \\
\hline PS10 & 0.9 & dry \\
\hline PS15 & 0.5 & dry \\
\hline
\end{tabular}

Based on the presented results (Table 2), the $\mathrm{pH}$ of all the recipes exhibits an alkaline reaction. The polymer shots' addition does not affect the $\mathrm{pH}$ of the concrete
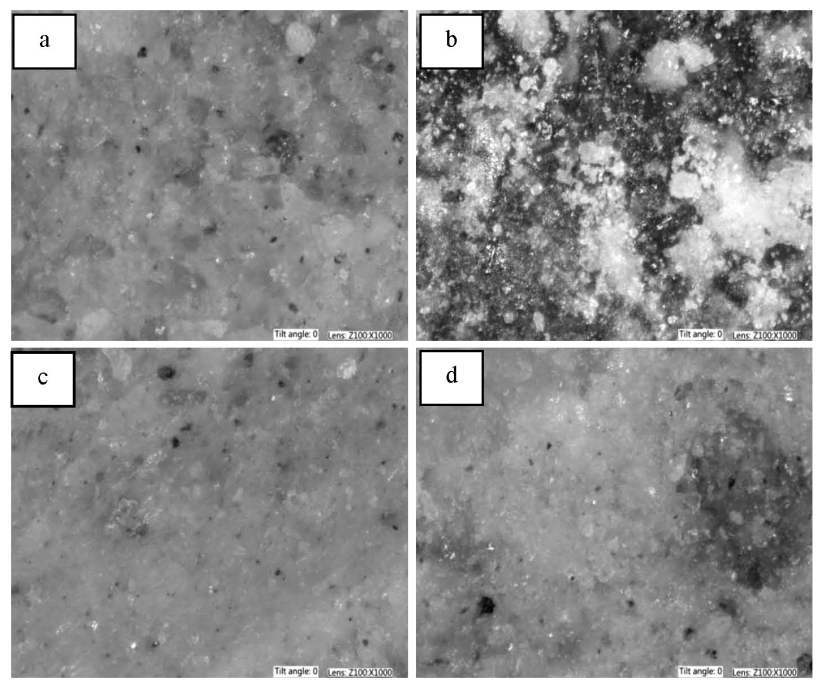

Figure 2: Results of the light-microscopy examination after the mechanical tests (a - reference, b-PS5, c - PS10, d - PS15) 


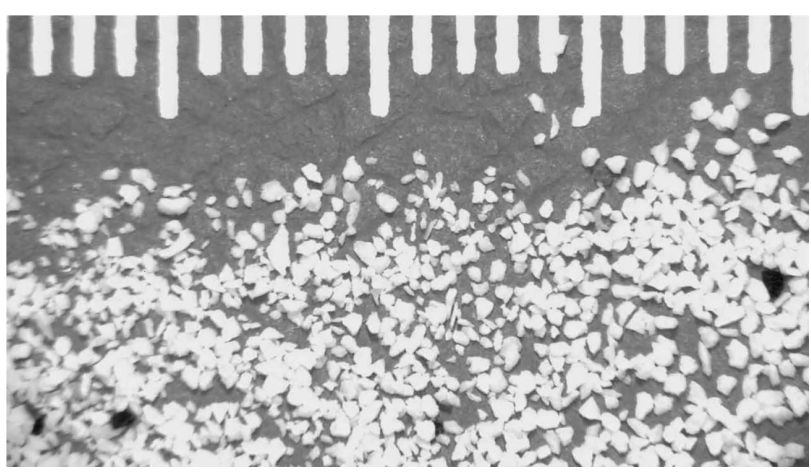

Figure 3: Microstructure of polymer shots

mix. However, during the concrete production and its care, the concrete mix did not reach the melting temperature of the shot or the softening temperature of the polymer, which can affect the $\mathrm{pH}$ value.

Table 2: The results of $\mathrm{pH}$ tests

\begin{tabular}{|c|c|}
\hline Recipe & $\mathrm{pH}$ \\
\hline Reference & 12.74 \\
\hline PS5 & 12.76 \\
\hline PS10 & 12.78 \\
\hline PS15 & 12.80 \\
\hline
\end{tabular}

The presented porosity test results (Figure 4) show that the quantity of polymeric shots slightly affects the quantity of pores in the concrete. An increase of the polymer shot in the concrete composite means that the quantity of pores increases. In order to reduce the pore surface, each time the fraction of polymer shot in the aggregate sieve curve should be taken into account. In this way a reduction of the pore quantity in the concrete will occur, which will affect the physical properties of the concrete positively.

Analyzing the results of the physics research (Figure 5), a decreasing effect on the thermal conductivity coefficient can be observed. The lowest value of the coefficient was obtained for the PS15 recipe $(15 w / \%$ of polymer

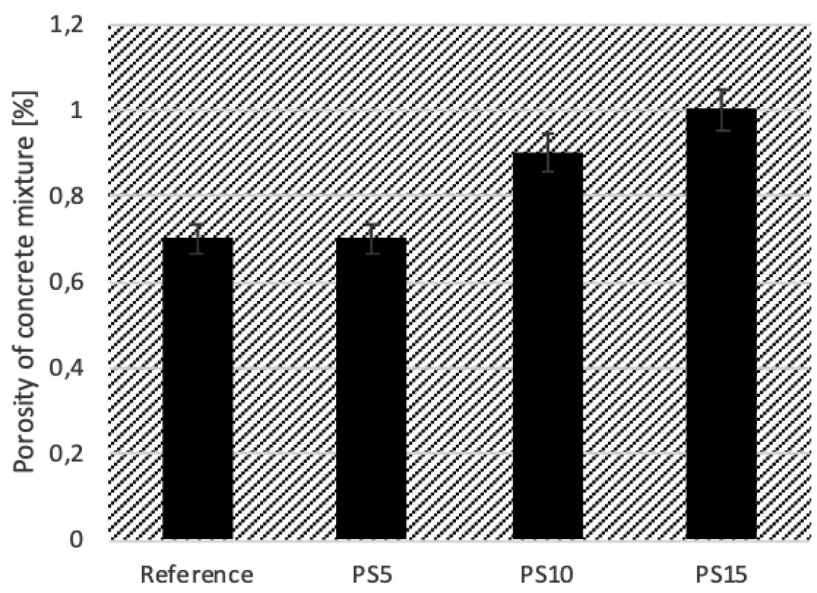

Figure 4: The porosity tests results

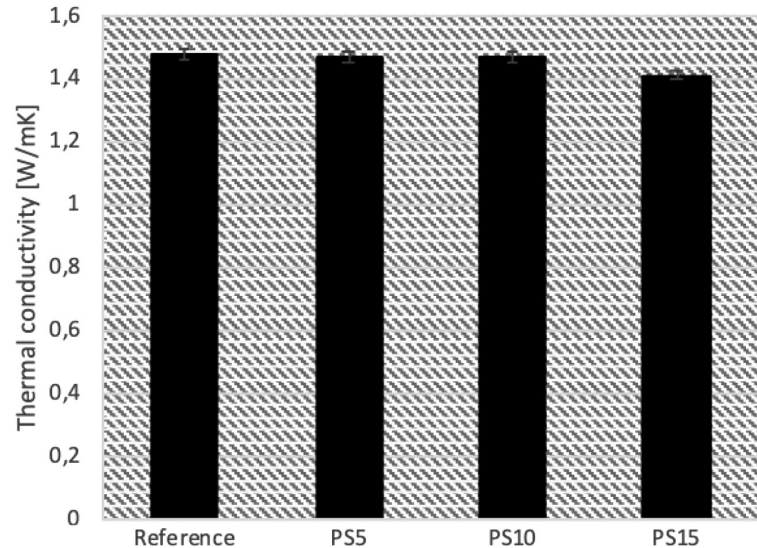

Figure 5: Thermal conductivity tests results

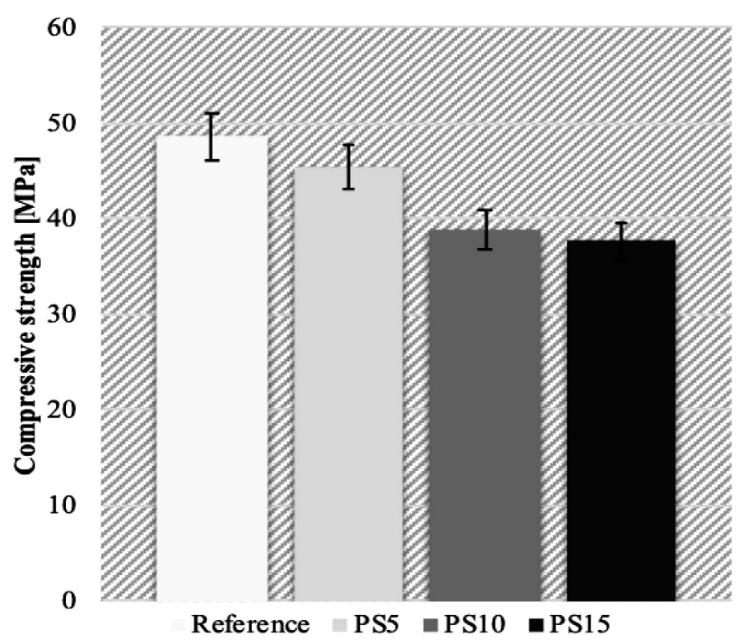

Figure 6: Compressive-strength test results

shots), i.e., $1.40 \mathrm{~W} / \mathrm{mK}$, and it is $4.8 \%$ lower than for the reference sample.

The test results presented in Figure 6 show that polymer shot is negatively affecting the compressive strength of the concrete. The decrease in the strength of modified

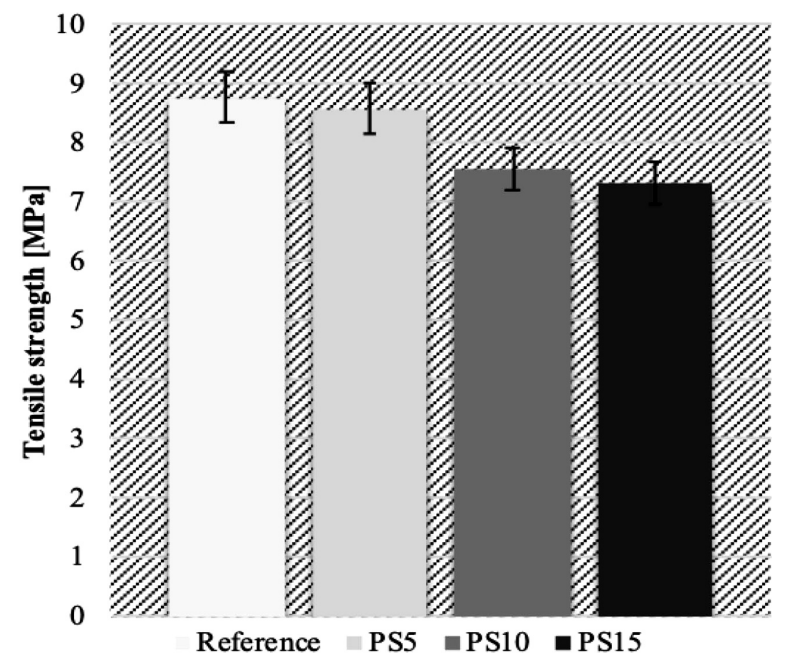

Figure 7: Tensile strength test results 
recipes results from the lower density of the polymer shot compared to the density of the cement and aggregate, and as the concrete density decreases, its compressive strength decreases.

A survey of the tensile-strength parameters after $28 \mathrm{~d}$ of the concrete samples is shown in Figure 7. Comparing with the reference sample, samples with the polymer-shots addition revealed lower values of tensile strength. All the studied amounts $(5 w / \%, 10 w / \%$ and $15 w / \%)$ showed a decreasing effect on the mechanical properties. Samples with $15 w / \%$ of polymer shots revealed the lowest values after bending, i.e., a $16 \%$ decrease of the tensile strength.

\section{DISCUSSION}

This article presents the results of concrete samples modified with polymer shots. The addition of polymer shots to the concrete mix resulted in a decrease in the value of the mechanical strength. The presented results (Figure 6 and 7) show that the addition of polymer shots reduces both the tensile and compressive strength of the tested samples. For an amount of $15 w / \%$, the largest decrease was observed. Analyzing the results of the non-hardened concrete mix tests, no negative impact of the polymer shots' addition on the concrete properties and physical properties was found. The quantity of the additive will not change the consistency and $\mathrm{pH}$ of the concrete mix. Only the porosity of mix was slightly increased. The hardened concrete samples, however, show a decrease in the thermal conductivity, which indicates a lower heat transfer. The newly obtained composite shows promise for applications in special constructions that should have a lower heat transfer.

\section{CONCLUSIONS}

The goal of determining the impact of polymer shots on concrete mixtures has been achieved. The article characterizes the effect of the additive on the properties of concrete. In concrete containing $5 \mathrm{w} / \%$ of polymer shots, no significant changes in the strength of the concrete, both compression and tensile, were observed. No problems in the mixing process during the production of concrete were detected. Furthermore, the production process is simple and possible to reproduce under normal environmental conditions. The study confirmed that it is possible to produce new concrete with less cement and comparable parameters.

\section{Acknowledgment}

Financial support of Research Statutory Program financed from Military University of Technology, Faculty of Civil Engineering and Geodesy: "Research of materials and construction elements of military infra- structure special objects", No. 886/2019 is gratefully acknowledged.

\section{REFERENCES}

${ }^{1}$ N. Gromicko, K. Shepard, The History of Concrete, https://www.nachi.org/history-of-concrete.htm\#ixzz31V47Zuuj, 13.09.2011

${ }^{2}$ H. Schliemann, W. Dörpfeld, F. Adler, Tiryns: The prehistoric palace of the kings of Tiryns, the results of the latest excavations, https://archive.org/details/bub_gb_pw4BAAAAMAAJ, 26.01.2015

${ }^{3}$ A. C. Sparavigna, Ancient concrete works, Dipartimento di Fisica, Politecnico di Torino, https://arxiv.org/ftp/arxiv/papers/1110/ 1110.5230.pdf, 24.10.2011

${ }^{4}$ W. Schmidta, M. Alexanderb, V. John, Education for sustainable use of cement based materials, Cement and Concrete Research 114 (2018), 103-114, doi:10.1016/j.cemconres.2017.08.009

${ }^{5}$ G. Girskas, G. Skripkiunas, G. Šahmenko, A. Korjakins, Durability of concrete containing synthetic zeolite from aluminum fluoride production waste as a supplementary cementitious material, Construction and Building Materials 117 (2016), 99-106, doi:10.1016/ j.conbuildmat.2016.04.155

${ }^{6}$ M. Malek, M. Jackowski, W. Życiński, M. Wachowski, Characterization of new filler additions affecting the mechanical strength of concrete, Mater. Technol. 53 (2019) 3, 399-403, doi:10.17222/ mit.2018.155

${ }^{7}$ A. Lotfy, O. Karahan, E. Ozbay, K. M. A. Hossain, M. Lachemi, Effect of kaolin waste content on the properties of normal-weight concretes, Construction and Building Materials 83 (2015); 102-107, doi:10.1016/j.conbuildmat.2015.03.002

${ }^{8}$ H. A. Favre, W. H. Powell, Nomenclature of organic chemistry: IUPAC recommendations and preferred names 2013, The Royal Society of Chemistry, Cambridge 2014, doi:10.1039/ 9781849733069-FP001

${ }^{9}$ N. Makul, G. Sua-iam, Effect of granular urea on the properties of self-consolidating concrete incorporating untreated rice husk ash: Flowability, compressive strength and temperature rise, Construction and Building Materials, 162 (2018), 489-502, doi:10.1016/ j.conbuildmat.2017.12.023

${ }^{10} \mathrm{~S}$. Mwaluwinga, T. Ayano, K. Sakata, Influence of urea in concrete, Cement and Concrete Research, 27 (1997) 5, 733-745, doi:10.1016/ S0008-8846(97)00051-3

${ }^{11}$ M. Suganya, D. Sathyan, K. M. Minic, Performance of concrete using waste fiber reinforced polymer powder as a partial replacement for fine aggregate, Materials Today: Proceedings 5 (2018) 11, part 3, 24114-24123, doi:10.1016/j.matpr.2018.10.205

${ }^{12}$ F. Moodi, A. Kashi, A. A. Ramezanianpour, M. Pourebrahimi, Investigation on mechanical and durability properties of polymer and latex-modified concretes, Construction and Building Materials, 191 (2018), 145-154, doi:10.1016/j.conbuildmat.2018.09.198

${ }^{13}$ S. Gwon, S. Y. Jang, M. Shina, Microstructure evolution and strength development of ultra rapid hardening cement modified with redispersible polymer powder, Construction and Building Materials, 192 (2018), 715-730, doi:10.1016/j.conbuildmat.2018.10.178

${ }^{14}$ M. M. Reda Taha, M. Genedy, Y. Ohama, 17 - Polymer concrete, developments in the formulation and reinforcement of concrete (Second edition), Woodhead Publishing Series in Civil and Structural Engineering, (2019), 391-408, doi:10.1016/B978-0-08102616-8.00017-4

${ }^{15}$ Z. Pavlík, M. Pavlíková, M. Záleská, 9 - Properties of concrete with plastic polypropylene aggregates, Use of Recycled Plastics in Eco-efficient Concrete, Woodhead Publishing Series in Civil and Structural Engineering, (2019), 189-213, doi:10.1016/B978-0-08102676-2.00009-8 